\title{
SURVIVAL EVALUATION AND SOIL REINFORCEMENT CAPACITY OF FIVE REOPHYTES SPECIES OF THE ATLANTIC RAINFOREST BIOME
}

\author{
Junior Joel Dewes ${ }^{1 *}$, Charles Rodrigo Belmonte Maffra ${ }^{1}$, Rita dos Santos Sousa ${ }^{1}$, Fabrício Jaques Sutili² \\ ${ }^{1}$ Federal University of Santa Maria (UFSM), Postgraduation Program in Forest Engineering, Santa Maria, state of Rio Grande do Sul, Brazil \\ - juniordewes2011@gmail.com*; charles.maffra@gmail.com; ritasousa.ufsm@ gmail.com \\ ${ }^{2}$ Federal University of Santa Maria (UFSM), Forest Sciences Department, Santa Maria, state of Rio Grande do Sul, Brazil - \\ fjsutili@gmail.com
}

Received for publication: 03/05/2018 - Accepted for publication: 08/11/2018

\begin{abstract}
Resumo
Avaliação da sobrevivência e capacidade de reforço do solo de cinco espécies reófitas do bioma mata atlântica. O objetivo deste trabalho foi avaliar a sobrevivência, o desenvolvimento vegetativo e a resistência ao arranquio de Phyllanthus sellowianus, Salix humboldtiana, Gymnanthes schottiana, Cephallanthus glabratus e Ludwigia elegans propagadas por estacas vivas. O experimento foi conduzido a campo na Universidade Federal de Santa Maria, RS. O experimento foi instalado em outubro (2015) e avaliado em junho (2016). O delineamento experimental utilizado foi blocos inteiramente casualizados com 5 espécies vegetais e 3 repetições. Cada bloco recebeu 3 estacas de cada espécie, totalizando 45 estacas. O espaçamento entre plantas foi de $1 \mathrm{x} 1 \mathrm{~m}$. Utilizaramse estacas com diâmetro médio de $1,7 \mathrm{~cm}$ e $60 \mathrm{~cm}$ de comprimento. Foi avaliada a taxa de sobrevivência, variáveis morfológicas da parte aérea, bem como a resistência ao arranquio para cada espécie. As taxas de sobrevivência observadas foram: P. sellowianus (100\%), S. humboldtiana (100\%), G. schottiana (83\%), C. glabratus $(67 \%)$ e L. elegans (50\%), as quais diferiram estatisticamente entre si pelo teste Qui-quadrado $\left(\chi^{2}\right)$ a $5 \%$ de probabilidade de erro. As variáveis, comprimento e diâmetro de brotos, assim como a resistência ao arranquio diferiram estatisticamente entre espécies pelo teste de Tukey a 5\% de probabilidade de erro, sendo que os melhores resultados foram observados para P. sellowianus e os menos promissores para L. elegans. Conclui-se que as espécies estudadas, exceto L. elegans, apresentaram de ótimas a boas taxas de sobrevivência. As espécies P. sellowianus e L. elegans apresentaram a maior e menor capacidade de reforço mecânico do solo, respectivamente.

Palavras-chave: Engenharia natural, recuperação de áreas degradadas, estabilização de solos, propagação vegetativa.
\end{abstract}

\begin{abstract}
The aim of this study was to evaluate the survival rate, the vegetative development and vertical pullout resistance of Phyllanthus sellowianus, Salix humboldtiana, Gymnanthes schottiana, Cephallanthus glabratus and Ludwigia elegans propagated by live cuttings. The experiment was conducted at the Federal University of Santa Maria, RS. The experiment was installed in October 2015 and evaluated in June 2016. Experiment was conducted in randomized blocks design with use of 5 plant species and 3 replications. In each block were planted 3 live cuttings of each species, with the total of 45 cuttings for the 3 blocks. The space between plants was of $1 \mathrm{x} 1 \mathrm{~m}$. Live cuttings average diameter was $1.7 \mathrm{~cm}$ and $60 \mathrm{~cm}$ long. Were evaluated the survival rate, morphological variables from shoots, as well as the vertical pullout resistance for each species. The observed survival rates were: P. sellowianus (100\%), S. humboldtiana (100\%), G. schottiana (83\%), \%), C. glabratus $(67 \%)$ e L. elegans (50\%), which are statistically different among themselves by Chi-square test $\left(\chi^{2}\right)$ at $5 \%$ level of significance. The variables, length and diameter of shoots, as well as the vertical pullout resistance are statistically different between species by Tukey's test at $5 \%$ level of significance, and the best results were observed for $P$. sellowianus and less favorable to L. elegans. The results showed that the evaluated species, excluding L. elegans, had from great to good survival rates. The species P. sellowianus and L. elegans had the major and minor soil mechanical reinforcement capacity, respectively.

Keywords: Soil Bioengineering, land reclamation, soil stabilization, vegetative propagation.
\end{abstract}

\section{INTRODUCTION}

Rivers present a distinct hydraulical dynamic and are in constant modification since their water flow behaves differently throughout its longitudinal profile. In the initial section processes of depth excavation occurs in the riverbed, while in final and medium sections excavation happens in the margins (DURLO; SUTILI, 2014). Therefore, fluvial systems are in continuous process of dynamic balance in which occur specific erosion, transport and deposition phenomena (STEVAUX; LATRUBESSE, 2017). Riparian vegetation contributes to the control of these erosive processes through soil stabilization by its radicular systems. The absence of riparian vegetation through watercourses, admittedly, results in preoccupying problems such as the increase of erosion rates at fluvial margins. It results in loss of areas suitable for agriculture, increase of floods susceptibility and infrastructure works damage due to riverbed sedimentation. 
In recent years, it has been increasing the preoccupation with degraded riparian forest restoration due to the reasons previously detached. Several techniques have been used to achieve such objective, amongst which the ones that result in an increase of hydraulical roughness, flow speed reduction and stability increase stand out, such as live rip-rap, krainer wall and brush mattress (DURLO; SUTILI, 2014; HACKER; JOHANNSEN, 2012; MAFFRA et al., 2017a; SOUSA et al., 2017; STUDER; ZEH, 2014).

In this case, unstable fluvial margins can be technically and ecologically recovered aiming to hydraulically stabilize watercourses and mitigate soil losses. Reophyte species are the most indicated for these recovery works together with or next to waterlines because they generally present small sizes, flexible stems and survive long submersion periods without damaging their vitality (SOUSA et al., 2017; SOUSA; SUTILI, 2017). However, resilience retake and the effective stabilization of the site depend on previous studies of biotechnical properties (technical and ecological) of plants to be used.

In order to proceed with these studies, the main factors to be evaluated are survival rate, shoot area growth and radicular system capacity to mechanically reinforce the soil (LIU et al., 2014). This last factor can be evaluated by resistance tests to vertical pullout of plants. This methodology has been described and employed in different places around the world (LIU et al., 2011; LIU et al., 2014; OSMAN et al., 2011; KARRENBERG et al., 2003), being characterized as recent and innovative for applications in Brazilian territory. Vertical pullout test allows to obtain capacity estimates of a plant in structure, reinforce and stabilize soil through its radicular system, serving as a comparison method between species.

The objective of this study was to evaluate survival, vegetative development and pullout resistance of Phyllanthus sellowianus (Klotsch) Müll. Arg., Salix humboldtiana Willd., Gymnanthes schottiana Müll. Arg., Cephallanthus glabratus (Spreng.) K. Schum. e Ludwigia elegans (Cambess.) H. Hara propagated through live cuttings.

\section{MATERIAL AND METHODS}

\section{Study place and experiment characteristics}

The experiment was carried out in an experimental area of Soil Bioengineering Laboratory (LabEN) (29 $43^{\prime} 02^{\prime}$ ' S and 53 $43^{\prime} 34^{\prime \prime}$ O), in the campus of Federal University of Santa Maria (UFSM), Santa Maria, state of Rio Grande do Sul, Brazil. The study place is $117 \mathrm{~m}$ above sea level and, according to Köppen classification, is characterized by presenting climate type Cfa subtropical humid (ALVARES et al., 2013), with average precipitation above $1500 \mathrm{~mm}$ and hottest month (January) average temperature of $25^{\circ} \mathrm{C}$ and coldest month (July) of $14^{\circ} \mathrm{C}$.

The experiment was installed in October 2015 (spring) and evaluated in June 2016 (fall), 8 months after planting. The experiment was conducted in randomized blocks design (RBD) with the use of 5 plant species and 3 replications for each species. In each block were planted 3 live cuttings of each species, that is, 15 cuttings to the 5 studied species, totalizing 45 cuttings for the 3 blocks. For each block, the adopted spacing between plants was $1 \mathrm{mx} 1 \mathrm{~m}$ and the area had $3 \mathrm{~m} \times 15 \mathrm{~m}$ of dimension, totalizing $45 \mathrm{~m}^{2}$.

The used species belongs to south Brazilian fluvial margins reophyte autochthonous flora, nominated: $P$. sellowianus (sarandi-branco), S. humboldtiana (salgueiro), G. schottiana (sarandi-vermelho), C. glabratus (sarandi-colorado) e L. elegans (cruz-de-malta).

Propagation by cuttings was the technique used to the plantation of the species. The length of the cuttings was $60 \mathrm{~cm}$ and $1.7 \mathrm{~cm}$ of average diameter. Each cutting was buried vertically $50 \mathrm{~cm}$ depth in the soil in order to minimize humidity loss in the stem. The planting of each cutting was performed in pits of $0.20 \mathrm{~m}$ of diameter and $0.50 \mathrm{~m}$ depth, previously opened by a motorized soil perforator.

\section{Survival rate}

The survival rate of each species was evaluated at 8 months after the planting. The cuttings that presented root and shoot development were considered alive.

\section{Species vegetative development}

Regarding the shoot area, the morphological variables were number, length, diameter of the base and shoot dry mass. These variables were quantified by manual counting (number), the use of caliper (diameter) and milimetric ruler (remaining length). The shoot dry mass was obtained after drying in a greenhouse at $65^{\circ} \mathrm{C}$ until constant weight.

The root system of each cutting was evaluated after the pullout. In order to do so, the buried length of each cutting was divided into 5 sections from the surface $(0-10 \mathrm{~cm}, 10-20 \mathrm{~cm}, 20-30 \mathrm{~cm}, 30-40 \mathrm{~cm}$ and $>40 \mathrm{~cm})$. In each section number, base diameter, remaining length and root remaining dry mass ware evaluated. These 
variables were quantified by manual counting (number), the use of caliper (diameter) and milimetric ruler (remaining length). The root dry mass was obtained after drying in a greenhouse at $65^{\circ} \mathrm{C}$ until constant weight.

\section{Resistance test to vertical pullout}

Pullout test consisted of applying a vertical ascending force until complete rupture and extraction of all root system of each cutting (plant) from soil. The test was conducted in the field with an adjustable tripod equipped with an automotive winch and a pulley system for pullout force application, as it can be observed in Figura 1.
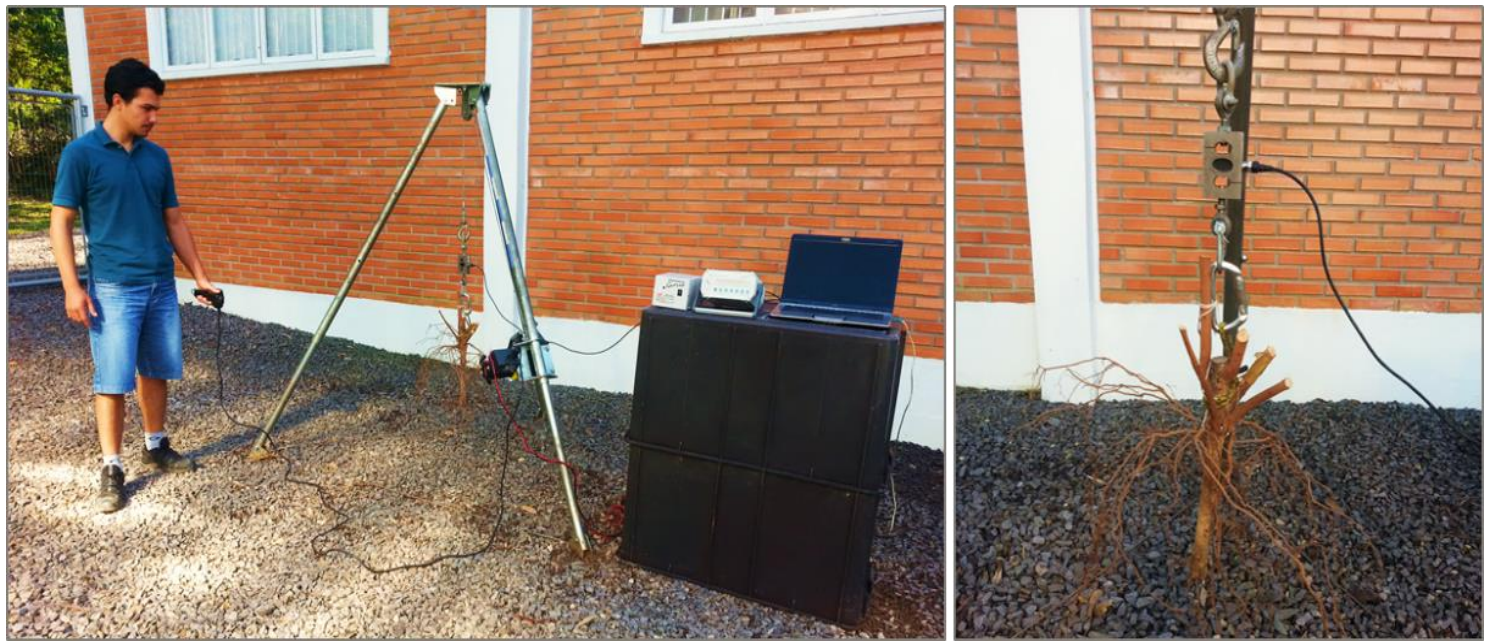

Figura 1. Equipamento utilizado para execução do arranquio das plantas (à esquerda) e detalhe de fixação da planta à célula de carga (à direita).

Figure 1. Equipment used for the execution of vertical pullout of plants (on the left) and fixing detail of the plant to the load cell (on the right).

Additionally, the machine has a load cell for determination of plants' resistive force. This cell is connected to a frequency transducer that transmits collected data to a laptop which stores them in a specific software. The collection of these data provided the maximum resistance to pullout $(\mathrm{kN})$ of each plant.

Each plant was fixed by a nylon rope to the load cell which was tied in a steel cable pulled by the winch. After that vertical pulling force was applied until disruption of the root system. Pullout resistance curve for each species with maximum peak and root system resistance post-peak were obtained due to cuttings displacement.

\section{Statistical analysis}

Species survival rate was submitted to Chi-square test $\left(\chi^{2}\right)$ at $5 \%$ error significance level. Data analysis was performed with statistical package Assistat version 7.7 and Microsoft Excel. Variance analysis (ANOVA) was carried out in order to test statistical differences between species in maximum resistance variation regarding observed pullout as well as morphological characteristics of shoot area and root system. Previously the data were submitted to variance homogeneity test (Bartlett, White, Cochran), independence test (Durbin-Watson), and residues normality test (Kolmogorov-Smirnov, Shapiro-Wilk, Anderson-Darling).

\section{RESULTS}

\section{Survival rate}

The best survival rate was obtained for P. sellowianus (100\%), S. humboldtiana (100\%) and G. schottiana (83\%), followed by C. glabratus (67\%) and L. elegans (50\%).

\section{Species vegetative development}

$P$. sellowianus species presented the best results in shoot area development, as much in length $(432.1 \mathrm{~cm})$ as in diameter $(38.3 \mathrm{~mm})$, and sprouts dry mass $(61.1 \mathrm{~g})$. G. schottiana species presented higher number of sprouts per cutting (9.5) however they had the smallest length among all the evaluated species, about $15.1 \mathrm{~cm}$ per sprout, resulting in low dry mass value $(3.7 \mathrm{~g})$. C. glabratus and L. elegans presented the lowest number of sprouts (3.6 and 3.7, respectively) and sprouts dry mass ( $3.5 \mathrm{~g}$ and $4.0 \mathrm{~g}$, respectively) between the studied species.

Tabela 1 indicates morphological characteristics variations observed in sprouts and roots development of the five studied species. 
Statistical tests revealed the existence of variance homogeneity, independence and normality of the residues to the level of significance $\mathrm{p}<0.05$.

ANOVA test revealed the existence of significant differences between the five species to length sum, diameter sum and sprout basal area sum variables. The species performance is presented in Tabela 1, in which are also presented the comparison of averages by Tukey test at $5 \%$ error probability.

Tabela 1. Resultados de F (ANOVA) e teste de comparação de médias (Teste de Tukey) para as características morfológicas das estacas das cinco espécies.

Table 1. F-test results (ANOVA) and comparison of averages test (Tukey-test) for the morphological characteristics of the live cuttings of the five species.

\begin{tabular}{|c|c|c|c|c|c|c|}
\hline Parameter & F (ANOVA) & PS $(\mathrm{N}=9)$ & $\mathrm{SH}(\mathrm{N}=9)$ & GS $(N=8)$ & CG $(\mathrm{N}=9)$ & LE $(N=4)$ \\
\hline Cutting diameter $(\mathrm{cm})$ & $5.28^{*}$ & $1.8 \pm 0.4 \mathrm{AB}$ & $2.2 \pm 0.2 \mathrm{~A}$ & $1.2 \pm 0.1 \mathrm{~B}$ & $1.3 \pm 0.2 \mathrm{AB}$ & $1.3 \pm 0.4 \mathrm{AB}$ \\
\hline \multicolumn{7}{|c|}{ SPROUTS } \\
\hline Length sum $(\mathrm{cm})$ & $5.98^{*}$ & $432.1 \pm 219.4 \mathrm{~A}$ & $260.3 \pm 14.6 \mathrm{AB}$ & $143.1 \pm 52.8 \mathrm{AB}$ & $77.9 \pm 3.1 \mathrm{~B}$ & $85.9 \pm 74.9 \mathrm{~B}$ \\
\hline Diameter sum (mm) & $5.99 *$ & $38.3 \pm 12.8 \mathrm{~A}$ & $25.0 \pm 2.8 \mathrm{AB}$ & $24.2 \pm 3.3 \mathrm{AB}$ & $12.7 \pm 5.1 \mathrm{~B}$ & $10.6 \pm 9.2 \mathrm{~B}$ \\
\hline Base area sum $\left(\mathrm{mm}^{2}\right)$ & $6.41^{*}$ & $247.4 \pm 139.0 \mathrm{~A}$ & $125.3 \pm 71.0 \mathrm{AB}$ & $61.7 \pm 17.6 \mathrm{~B}$ & $41.9 \pm 11.9 \mathrm{~B}$ & $29.1 \pm 26.3 \mathrm{~B}$ \\
\hline Number & $3.25 \mathrm{~ns}$ & $5.8 \pm 0.4 \mathrm{~A}$ & $5.6 \pm 1.3 \mathrm{~A}$ & $9.5 \pm 2.2 \mathrm{~A}$ & $3.6 \pm 2.1 \mathrm{~A}$ & $3.7 \pm 3.4 \mathrm{~A}$ \\
\hline Dry mass $(\mathrm{g})$ & $2.78 \mathrm{~ns}$ & $61.1 \pm 56.4 \mathrm{~A}$ & $31.2 \pm 40.8 \mathrm{~A}$ & $3.7 \pm 3.2 \mathrm{~A}$ & $3.5 \pm 2.8 \mathrm{~A}$ & $4.0 \pm 3.7 \mathrm{~A}$ \\
\hline \multicolumn{7}{|c|}{ ROOT } \\
\hline Number & $1.86 \mathrm{~ns}$ & $71.0 \pm 17.8 \mathrm{~A}$ & $115.0 \pm 45.3 \mathrm{~A}$ & $115.0 \pm 45.3 \mathrm{~A}$ & $30.0 \pm 13.3 \mathrm{~A}$ & $94.0 \pm 95.5 \mathrm{~A}$ \\
\hline Diameter next to cutting (mm) & $14.62 * *$ & $1.1 \pm 0.2 \mathrm{AB}$ & $0.6 \pm 0.1 \mathrm{BC}$ & $1.2 \pm 0.1 \mathrm{AB}$ & $1.6 \pm 0.4 \mathrm{~A}$ & $0.3 \pm 0.3 \mathrm{C}$ \\
\hline Rupture point diameter (mm) & $7.44 * *$ & $0.7 \pm 0.2 \mathrm{~A}$ & $0.4 \pm 0.1 \mathrm{AB}$ & $0.9 \pm 0.2 \mathrm{~A}$ & $0.9 \pm 0.4 \mathrm{~A}$ & $0.1 \pm 0.1 \mathrm{~A}$ \\
\hline Remaining length $(\mathrm{cm})$ & $3.65 \mathrm{~ns}$ & $6.6 \pm 0.5 \mathrm{~A}$ & $3.1 \pm 1.1 \mathrm{~A}$ & $6.8 \pm 3.3 \mathrm{~A}$ & $4.9 \pm 1.9 \mathrm{~A}$ & $2.7 \pm 2.4 \mathrm{~A}$ \\
\hline Base area next to cutting $\left(\mathrm{mm}^{2}\right)$ & $8.25^{* *}$ & $1.7 \pm 0.8 \mathrm{AB}$ & $1.0 \pm 0.9 \mathrm{~B}$ & $1.7 \pm 0.1 \mathrm{AB}$ & $3.0 \pm 1.4 \mathrm{AB}$ & $0.3 \pm 0.4 \mathrm{~B}$ \\
\hline Rupture in base area $\left(\mathrm{mm}^{2}\right)$ & $4.28^{*}$ & $0.7 \pm 0.3 \mathrm{AB}$ & $0.8 \pm 0.8 \mathrm{AB}$ & $1.1 \pm 0.1 \mathrm{AB}$ & $1.2 \pm 0.6 \mathrm{~A}$ & $0.1 \pm 0.1 \mathrm{~B}$ \\
\hline Remaining dry mass (g) & $57.26^{* *}$ & $6.3 \pm 1.0 \mathrm{~A}$ & $0.8 \pm 0.6 \mathrm{~B}$ & $1.1 \pm 0.8 \mathrm{~B}$ & $0.8 \pm 0.1 \mathrm{~B}$ & $0.8 \pm 0.7 \mathrm{~B}$ \\
\hline
\end{tabular}

Legend: PS (P. sellowianus), SH (S. humboldtiana), GS (G. schottiana), CG (C. glabratus) and LE (L. elegans), ( $\mathrm{N}=$ number of cuttings). In the rows, values followed by different letters indicate significative difference between species by Tukey test at $5 \%$ significance level $(* \mathrm{P}<$ 0.05 ; ** $\mathrm{P}<0.01 ;$ ns: non-significative)

A detailed analysis of root systems (Figura 2) indicates that number mean values, remaining diameter and dry mass were different along the cutting for the five studied species. All of them tended to develop greater root number next to the base of the cutting $(>30 \mathrm{~cm})$.

In relation to root diameter, P. sellowianus, G. schottiana and L. elegans presented thicker roots in initial sections, between 0-20 cm of depth. S. humboldtiana and $C$. glabratus species presented thicker diameters between 30-40 cm of depth, and C. glabratus presented highly superior root diameters than the ones verified to $S$. humdoldtiana.

$P$. sellowianus species presented higher remaining root dry mass after the pullout. Remaining root dry mass throughout the cutting diminished as the depth increased for some species.
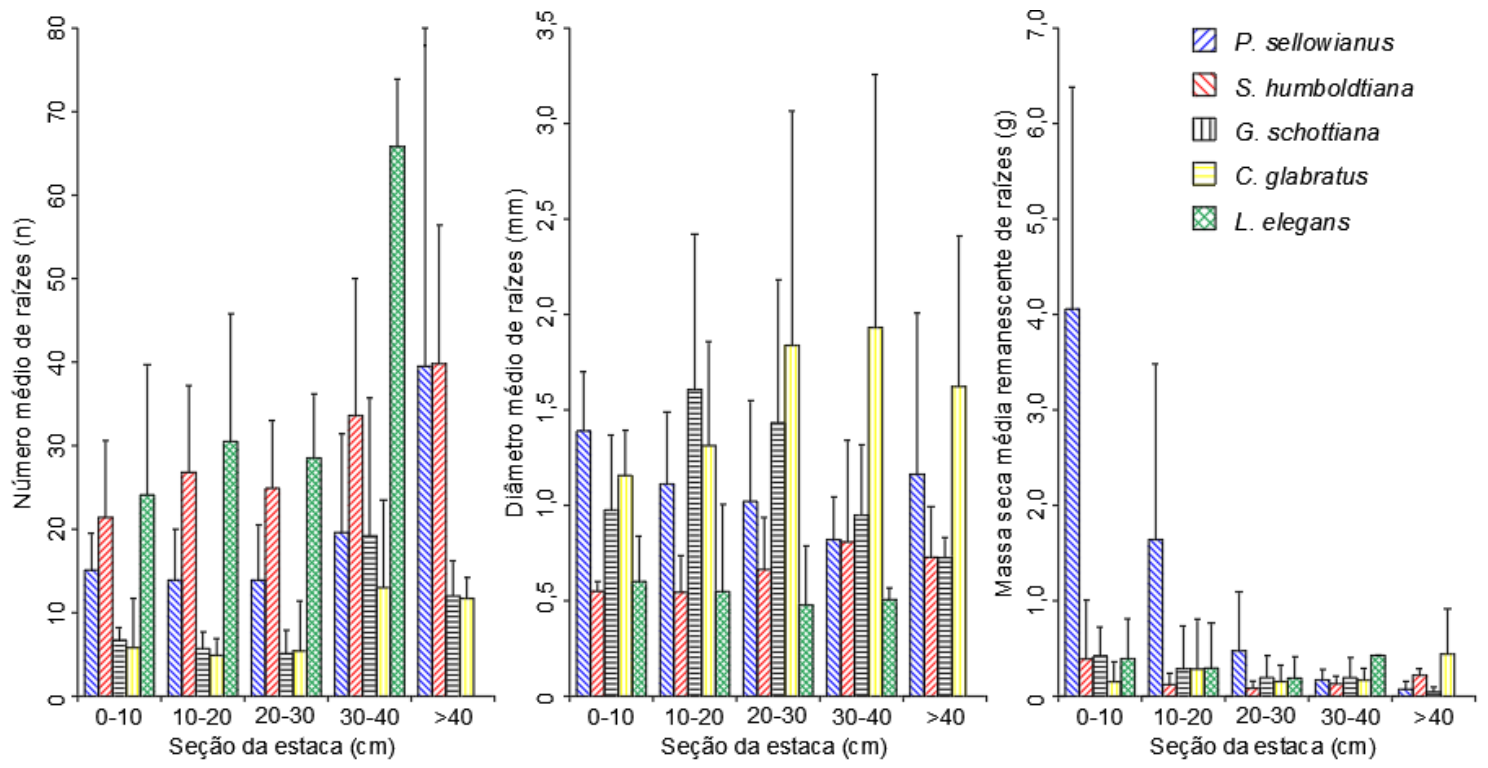
Figura 2. Número médio, diâmetro médio e massa seca remanescente média de raízes em função da seção da estaca para as cinco espécies estudadas.

Figure 2. Average number, average diameter and average dry mass of remaining roots depending on the section of the live cutting for the five studied species.

\section{Resistance test to vertical pullout}

Amongst the evaluated species, $P$. sellowianus presented the highest maximum resistance mean value to pullout $\left(\mathrm{F}_{\text {max }}\right.$ (mean maximum strength) $(0.444 \pm 0.148 \mathrm{kN})$, followed by $S$. humboldtiana $(0.397 \pm 0.152 \mathrm{kN}), G$. schottiana $(0.282 \pm 0.087 \mathrm{kN})$, C. glabratus $(0.221 \pm 0.091 \mathrm{kN})$ and L. elegans $(0.151 \pm 0.016 \mathrm{kN})$. The values of pullout resistance vary significantly between species in Tukey test, at $5 \%$ probability error level $(\mathrm{P}<0.05)$, as can be observed in Figura 3.

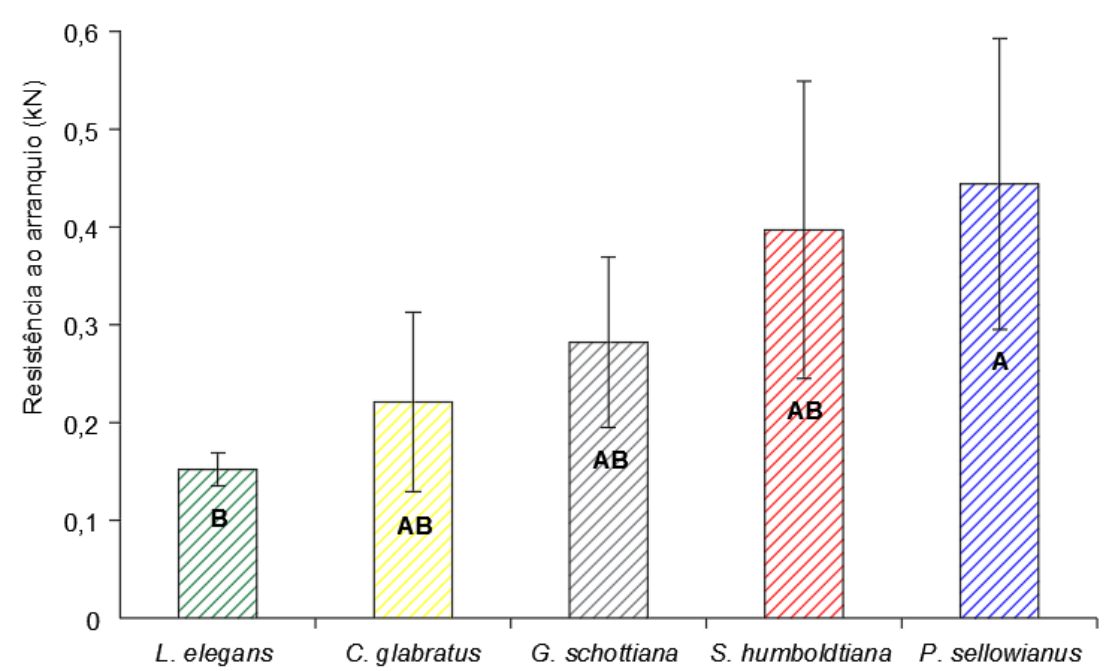

Figura 3. Resistência máxima média ao arranquio (média \pm desvio padrão) das cinco espécies analisadas. Valores seguidos de letras diferentes indicam diferença significativa entre espécies pelo teste de Tukey ao nível de $5 \%$ de probabilidade de erro.

Figure 3. Average maximum vertical pullout resistance (average \pm standard deviation) of the five analyzed species. Values followed by different letters indicate a significant difference between species by the Tukey's test at a probability level of $5 \%$.

Figura 4 presents pullout resistance curve behavior developed by each species.

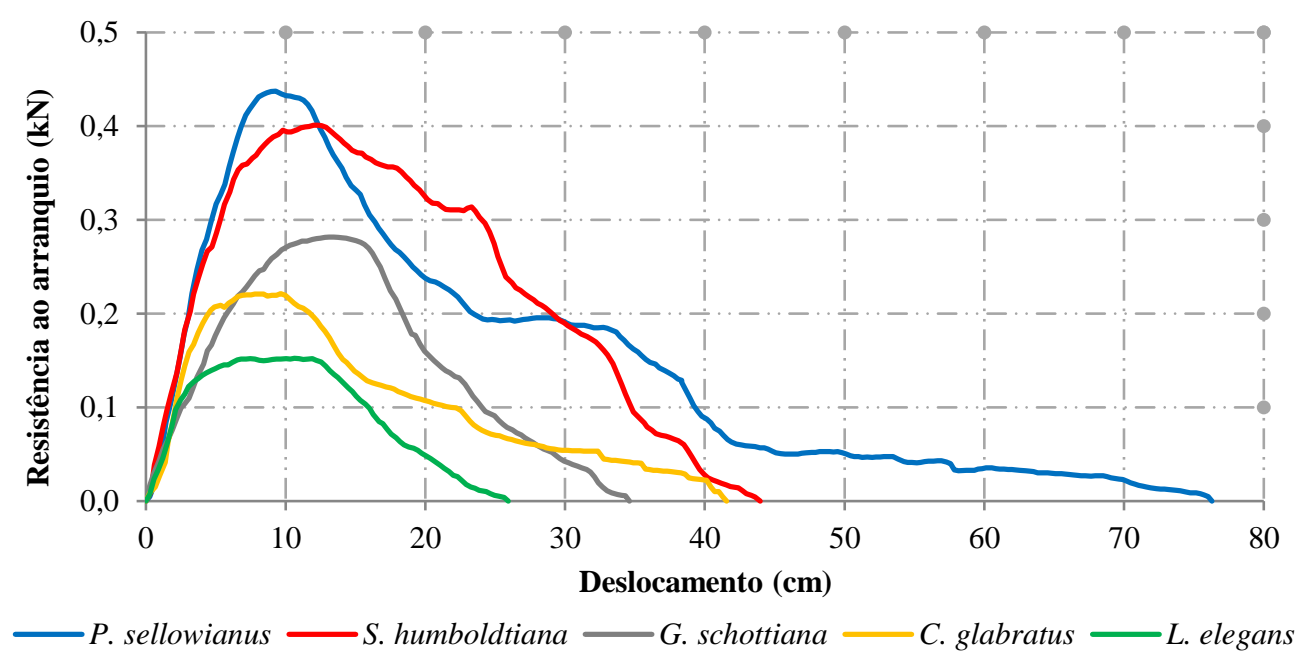

Figura 4. Curvas médias de resistência ao arranquio em função do deslocamento das estacas dentro do solo (extração por arranquio) para as cinco espécies estudadas.

Figure 4. Average curves of vertical pullout resistance depending on the displacement of the live cuttings within the ground (extraction by vertical pullout) for the five studied species. 
All species' curves behave alike since the beginning of the test until $2 \mathrm{~cm}$ of cutting displacement. After this point resistance curve behavior begins to differentiate. While L. elegans is reaching its maximum resistance peak, $P$. sellowianus and $S$. humboldtiana species keep resisting proportionally higher tensions.

Before the resistance maximum peak, or tension ascending phase, it can be observed intermediate resistance peaks in some curves, as in S. humboldtiana and C. glabratus.

Beyond that, resistance peak also occurred after maximum peak, as it is the case of $P$. sellowianus and $S$. humboldtiana (Figura 4). The occurrence of peaks after maximum peaks is usually due to roots located next to soil surface (section $0-10 \mathrm{~cm}$ ).

\section{DISCUSSION}

\section{Survival rate}

Survival rate recommended to vegetal species applied in degraded area recovery is at least 70\% (SAULI et al., 2003), because good survival rates are necessary in order to contribute to a fast cover and soil superficial protection against erosive agents such as water and wind (LIU et al., 2014).

In that way, only cutting propagation of L. elegans $(50 \%)$ presented unsatisfactory and much inferior to recomended results. $P$. sellowianus and S. humboldtiana presented excellent survival rates (100\%), while $G$. schottiana $(83 \%)$ results can be considered good. C. glabratus $(67 \%)$ cuttings survival is near to the recommended, and can be considered as satisfactory.

Survival rates results availability of the studied species still is very incipient. However, according to Reitz et al. (1988), despite $P$. sellowianus and G. schottiana species being preferably associated to riparian environments, they are able to support large periods without rain, demonstrating high hardiness, what can partially explain the survival rates observed in this experiment. To $S$. humboldtiana, the same authors affirm that the species present high cutting reproduction capacity, what was confirmed by the excellent result obtained in this study.

Sutili et al. (2018) report good survival rates to P. sellowianus (100\%), S. humboldtiana (96\%) and $G$. schottiana $(77 \%)$ species vegetatively propagated in field experimental seedbed of cuttings collected during autumn and winter, recommended moment in which the vegetation is in vegetative rest.

\section{Species vegetative development}

Development of shoot area, more specifically about sprouts and biomass production which are parameters that reflect cutting-propagated plants capacity to confer soil superficial coverage (PETRONE; PRETI, 2010). Regarding this, the evaluated species grew rapidly and provided good soil superficial protection, which is a primordial condition to soil conservation.

Sutili et al. (2018) observed growth rhythms similar to the ones observed in this study to P. sellowianus, S. humboldtiana and G. schottiana species. According to the authors, P. sellowianus, S. humboldtiana and G. schottiana species presented sprouts' length sum of $115 \mathrm{~cm}, 140 \mathrm{~cm}$ and $95 \mathrm{~cm}$, respectively, for cuttings propagated in field experimental seedbed. The values obtained are inferior to the ones obtained in this experiment, probably because their experiment was carried out in a time of the year that is less favorable to vegetative development compared to this experiment. Beyond that, the authors also observed a lower number of sprouts to $P$. sellowianus (4) and G. schottiana (8) compared to this experiment, with the exception of S. humboldtiana (7) species.

Due to the pioneering character of C. glabratus and L. elegans field vegetative development study, it was not possible to compare the obtained results of these species with other studies already carried out.

In relation to root system, the choice of plants for the use in soil stabilization studies must lie on species that produce great number and volume of roots, both adventitious roots and tap roots (SOUSA; SUTILI, 2017). In this direction, cuttings root development analysis showed that all studied species developed a great number of roots (Table 1). S. humboldtiana and L. elegans produced the greatest amount of root (115 and 94, respectively), and the lowest number was observed for C. glabratus (30). It was observed, then, that all species tended to develop greater root number next to the cutting base $(>30 \mathrm{~cm})$. Root development next to the cuttings' base has been associated with the position which the cuttings are inserted in the soil. Several authors indicate that cuttings' planting in vertical position stimulates auxin displacement (hormones responsible to rooting) from apical direction to basal direction (RAVEN et al., 1996; TAIZ; ZEIGER, 2013), which provokes a higher root development in the cuttings' base region (SCHIECHTL, 1973).

Regarding diamenter, C. glabratus was the species that developed the thickest diameters next to the cutting $(1.6 \mathrm{~mm})$, followed by $G$. schottiana $(1.2 \mathrm{~mm})$ and P. sellowianus $(1.1 \mathrm{~mm})$, S. humboldtiana $(0.6 \mathrm{~mm})$ and $L$. elegans $(0.3 \mathrm{~mm})$. In soil superficial stabilization it is preferable the occurrence of thin roots, once these roots provide higher soil containment and structuring in comparison to thick roots, contributing for superficial soil loss minimization (COPPIN; RICHARDS, 2007). Vertical roots and the ones with thicker diameters are preferable 
in the cutting's base, what allows best anchoring of soil mass contained by the plant (COPPIN; RICHARDS, 2007; SUTILI et al., 2018). In this way, vertical and thicker roots contribute to higher proportion in depth soil stabilization.

The higher remaining root dry mass after pullout was verified to P. sellowianus. It is due to the fact of this species has developed many roots of thicker diameter closer to soil surface. Besides, roots of this species present great individual resistance to rupture, which, during the pullout, allowed them to shear the soil and had a good part of their length extracted, rupturing at higher distances from the cutting.

Remaining root dry mass throughout the cutting diminished as the depth increased for some species. One of the reasons for this assertion is the tendency of roots located in higher depths to rupture closer to the cutting because of a bigger layer of soil on top of them. Soil weight allows less root lateral deformation, in a way that many of them are sheared directly next to the cutting during the pullout.

G. schottiana and P. sellowianus, compared to the other tested species presents the biggest mean root remaining lengths $(6.8$ and $6.6 \mathrm{~cm}$, respectively). This means that the roots of these two species ruptured in point afar from the cuttings, according to the data presented in Tabela 1 and reinforced by field observation.

\section{Resistance test to vertical pullout}

Between all species, $P$. sellowianus presented the highest pullout resistance $(0.444 \pm 0.148 \mathrm{kN})$ and due to this, it possesses higher potential to strengthen the soil by its root system. On the other hand, $C$. glabratus and $L$. elegans species presented the lowest capacity to strengthen the soil. The roots of these last two species demonstrate to possess low individual resistance when manually pulled due to a high hydric content associated to a spongy aspect, what possibly resulted in less pullout maximum resistance (Figura 3 and Figura 4).

In vertical resistance pullout test carried out by Liu et al. (2014) using shrub and tree species propagated by cuttings, the authors obtained mean maximum resistance values between $0.76 \mathrm{kN}$ and $1.21 \mathrm{kN}$ after 12 months of experiment setting. Values between $0.16 \mathrm{kN}$ and $0.19 \mathrm{kN}$ were observed by Karrenberg et al. (2003) for Populus nigra L. and Salix elaeagnos Scopoli after 3 months of cutting propagation. Liu et al. (2011), in turn, observed for Salix alba var. tristis mean maximum resistance to vertical pullout around $2.04 \mathrm{kN}$ in cuttings after 4 years of plantings. Comparing the values reported by the authors, the resistance to pullout was especially satisfactory to $P$. sellowianus, S. humboldtiana and G. schottiana species.

During cuttings pullout, it can occur intermediate resistance peaks in the characteristic curves of the species, as observed for S. humboldtiana and C. glabratus (Figura 4). This occurs because the roots are not pulled all at the same time and with the same force, causing premature rupture of some roots, having considerable importance in total maximum resistance (MAFFRA et al., 2017b). This behaviour can be related to several factors, such as architecture, inserting angle, root position along the cutting, among others (COPPIN; RICHARDS, 2007).

The occurrence of resistance peaks also can happen after the maximum peak, as observed for $P$. sellowianus and S. humboldtiana. This occurs generally by roots that are located next to the soil surface (section $0-10 \mathrm{~cm}$ ) and ruptured last because they can shear a small soil layer on top of them during the pullout. The extraction of great part of its length from the soil results in ruptures at larger distances from the cutting, increasing also the total vertical displacement necessary until the rupture of all root system. $P$. sellowianus clearly presented this behaviour, confirmed by the highest cutting mean displacement $(76.29 \mathrm{~cm})$ necessary to the total pullout compared to the other species. The biggest remaining root dry mass between $0-10 \mathrm{~cm}$ for this species also reinforces this argument (Figura 2).

Despite all five species present different resistance curves, the vertical displacement of the cuttings until their root system rupture (maximum peak) were sufficiently similar. P. sellowianus and C. glabratus reached their maximum peaks after $9 \mathrm{~cm}$ of cutting vertical displacement, followed by L. elegans with $10 \mathrm{~cm}$ and $S$. humboldtiana with $12 \mathrm{~cm}$. The biggest displacement until maximum peak was observed for G. schottiana, with $13 \mathrm{~cm}$. This suggests that, independently of more resistant (P. sellowianus, S. humboldtiana) and less resistant ( $C$. glabratus and L. elegans) root systems, they tend to present a similar mechanic behaviour, rupturing in similar moments when requested.

\section{CONCLUSIONS}

- P. sellowianus, S. humboldtiana, G. schottiana and C. glabratus present good survival rates while L. elegans presents less satisfactory results;

- The analysis allows to evidence that there was significative difference in vegetative development of the species, as much for the shoot as for root system. The best results are verified for P. sellowianus and $S$. humboldtiana, and the less promising for L. elegans.

- The highest maximum resistance to pullout are observed for $P$. sellowianus, certifying its highest capacity in soil reinforcement amongst all studied species. L. elegans presents the lowest resistance values. 
- The P. sellowianus species responds more successfully to the evaluated variable, being, therefore, the most indicated between all the evaluated species for the use in slope stabilization and degraded areas recovery works.

- The obtained results contribute to technical knowledge increase regarding field development of the studied species, as well as to a better understanding of its technical functions for use in slope and hillside stabilization works.

\section{REFERENCES}

ALVARES, C. A.; STAPE, J. L.; SENTElHAS, P.C.; GONCALVES, J. L. M.; SPAROVEK, G. Köppen's climate classification map for Brazil. Meteorologische Zeitschrift, v. 22, n. 6, p. 711 - 728, 2013.

COPPIN, N. J.; RICHARDS, I. G. Use of Vegetation in Civil Engineering. London, UK: Construction Industry Research and Information Association (CIRIA), 2 ed. 2007, 238 p.

DURLO, M.; SUTILI, F. Bioengenharia - Manejo biotécnico de cursos de água. Santa Maria: Pallotti, 3 ed. 2014 , $192 \mathrm{p}$.

HACKER, E.; JOHANNSEN, R. Ingenieurbiologie. Stuttgart: UTB Ulmer, 1 ed. 2012, 383 p.

KARRENBERG, S.; BLASER, S.; KOLLMANN, J.; SPECK, T.; EDWARDS, P.J. Root anchorage of saplings and cuttings of woody pioneer species in a riparian environment. Functional Ecology, v. 17, n. 2, p. 170 - 177, 2003.

LIU, Y.; GAO, J.; LOU, H.; CUI, Q. The root anchorage ability of Salix alba var. tristis using a pull-out test. African Journal of Biotechnology, v. 10, n. 73, p. 16501 - 16507, 2011.

LIU, Y.; RAUCH, H. P.; ZHANG, J.; YANG, X.; GAO, J. Development and soil reinforcement characteristics of five native species planted as cuttings in local area of Beijing. Ecological engineering, v. 71, p. 190 - 196, 2014.

MAFFRA, C. R. B.; MORAES, M. T.; SOUSA, R. S.; SUTILI, F. J.; PINHEIRO, R. J. B.; SOARES, J. M. D. Métodos de avaliação da influência e contribuição das plantas sobre a estabilidade de taludes. Scientia Agraria, v. 18, n. 4, p. $129-143,2017 b$.

MAFFRA, C. R. B.; SOUSA, R. S.; SUTILI, F. J. Engenharia Natural para estabilização de travessia dutoviária - Caso 2. Ciência \& Ambiente, v. 46/47, p. 153 - 176, 2017a.

OSMAN, N.; ABDUlLAH, M. N.; ABDUllaH, C. H. Pull-Out and Tensile Strength Properties of Two Selected Tropical Trees. Sains Malaysiana, v. 40, n. 6, p. 577-585, 2011.

PETRONE, A.; PRETI, F. Soil bioengineering for risk mitigation and environmental restoration in a humid tropical area. Hydrology and Earth System Sciences, v. 14, n. 2, p. 239 - 250, 2010.

RAVEN, P. H.; EVERT, R. F.; EICHHORN, S. E. Biologia vegetal. Rio de Janeiro: Guanabara Koogan S.A., 5 ed. 1996, $728 \mathrm{p}$.

REITZ, R.; KLEIN, R. M.; REIS, A. Projeto madeira do Rio Grande do Sul. Brasil: Superintendência do Desenvolvimento da Região Sul - Governo do Estado do Rio Grande do Sul (RS) - Herbário Barbosa Rodrigues, 1 ed. $1988,525 \mathrm{p}$.

SAULI, G.; CORNELINI, P.; PRETI, F. Manuale d' Ingegnaria Naturalistica Applicabile ai Settori delle Strade, Cave, Discariche e Coste Sabbiose. Roma, Itália: Regione Lazio, 1 ed. 2003, 591 p.

SCHIECHTL, H. Bioingegneria Forestale. basi - materiali da construzioni vivi - metodi. Itália: Edizione CastaldiFeltre, 1 ed. 1973, 263p.

SOUSA, R. S.; MAFFRA, C. R. B.; SUTILI, F. J. Engenharia Natural para estabilização de travessia dutoviária - Caso 1. Ciência \& Ambiente, v. 46/47, p. 131 - 152, 2017.

SOUSA, R. S.; SUTILI, F. J. Aspectos Técnicos das Plantas utilizadas em Engenharia Natural. Ciência \& Ambiente, v. 46/47, p. $31-71,2017$.

STEVAUX, J. C.; LATRUBESSE, E. M. Geomorfologia fluvial. São Paulo: Oficina de Textos, 1 ed. 2017,366 p.

STUDER, R.; ZEH, H. Soil Bioengineering: Construction Type Manual. Zurich: vdf Hochschulverlag an der ETH, 2 ed. 2014,439 p.

SUTILI, F. J.; DORNELES, R. S.; VARGAS, C. O.; KETTENHUBER, P. L. W. Avaliação da propagação vegetativa de espécies utilizadas na estabilização de obras de terra com técnicas de Engenharia Natural. Ciência Florestal, v. 28, n. 1, p. 1 - 12, 2018.

TAIZ, L.; ZEIGER, E. Fisiologia vegetal. Porto Alegre: Artmed Editora; 5 ed. 2013, 954 p. 